\title{
Class 1 Integrons and the Antibiotic Resistance Profile of Salmonella Infantis Strains from Broiler Chickens
}

\author{
İnci Bașak KAYA '\& Özlem ŞAHAN YAPICIER ${ }^{2}$ \\ Mehmet AKAN ' Kadir Serdar DIKER '
}

${ }^{1}$ Ankara Üniversitesi Veteriner Fakültesi Mikrobiyoloji Anabilim Dalı, TR-06110 Dışkapı, Ankara - TURKEY

${ }^{2}$ Mehmet Akif Ersoy Üniversitesi, Veteriner Fakültesi Mikrobiyoloji Anabilim Dalı, TR-15030 İstiklal Yerleşkesi, Burdur TURKEY

Article Code: KVFD-2017-17821 Received: 30.03.2017 Accepted: 06.06.2017 Published Online: 07.06.2017

Citation of This Article

Kaya İB, Şahan Yapıcıer Ö, Akan M, Diker KS: Class 1 integrons and the antibiotic resistance profile of Salmonella infantis strains from broiler chickens. Kafkas Univ Vet Fak Derg, 23 (5): 803-807, 2017. DOI: 10.9775/kvfd.2017.17821

\begin{abstract}
Salmonella infections are one of the most important diseases and cause economic problems in poultry. The zoonotic feature of the agent and leading to food-borne infections are also important in public health issues. Increasing antibiotic resistance causes difficulties of controlling Salmonella infections, in recent years. Among non-typhoidal Salmonella serotypes the rate of Salmonella Infantis are increasing in Turkey. With this increase, it is important to know the antimicrobial resistance patterns of Salmonella Infantis strains as seen in other Salmonella serotypes. In this study, we aimed to investigate Salmonella Infantis strains which were isolated from feces of healthy broiler chickens for the presence of antibiotic resistance and frequency of Class 1 integrons that is responsible for the transfer of antibiotic resistance as plasmids, transposons. For this purpose a total of $150 \mathrm{~S}$. Infantis strains which were isolated and identified according to the ISO 6579-2002 and Kauffmann-White serotyping scheme were used. Antimicrobial resistance of the strains was determined by the disc diffusion method following to the recommendations of CLSI 2011 standard protocol and also Class 1 integrons were investigated by PCR. According to the results, high rate of multi-drug antibiotic resistance $(89.3 \%)$, high rate of sensitivity $(100 \%)$ to cefotaxime, ciprofloxacin, gentamicin, ceftazidime were observed and also Class 1 integrons were determined in all isolates. In conclusion, the presence of Class 1 integron is all strains of Salmonella Infantis showed the potential importance of these strains as recipient for antibiotic resistance.
\end{abstract}

Keywords: Antimicrobial resistance, Class 1 integron, Salmonella Infantis

\section{Broyler Tavuklardan Elde Edilen Salmonella Infantis Suşlarının Antibiyotik Direnç Profilleri ve Sınıf 1 İntegron Varlığı}

\begin{abstract}
Özet
Salmonella infeksiyonları kanatlı hayvanlarda görülen ve ekonomik kayıplara neden olan en önemli hastalıklardan biridir. Etkenin zoonotik karakteri ve gıda kaynaklı infeksiyonlara neden olması da halk sağlığı açısından önem göstermektedir. Son yıllarda artan antibiyotik dirençliliği Salmonella infeksiyonlarının kontrolünü güçleştirmektedir. Türkiye'de non-tifoidal Salmonella serotiplerinden Salmonella Infantis'in oranı artış göstermektedir. Bu artış ile birlikte, diğer Salmonella serotiplerinde yaygın olarak görülen antimikrobiyal dirençliliğin Salmonella Infantis suşlarında da bilinmesi önem taşımaktadır. Bu çalışmada, sağlıklı broyler tavukların dışkılarından izole edilen Salmonella Infantis suşlarında antibiyotik dirençliliği ve plasmidler, transpozonlar gibi antibiyotik dirençliliğinin taşınmasında rol oynayan sınıf 1 integronların sıklığının araştırılması amaçlandı. Bu amaçla ISO 6579-2002 ve Kauffmann-White serotiplendirme şemasına göre identifiye edilen 150 adet Salmonella Infantis suşu kullanıldı. Suşların antibiyotik dirençleri CLSI 2011 standart protokolüne göre disk difüzyon yöntemi ile belirlendi ve PZR ile sınıf 1 integronlar araştırıldı. Elde edilen sonuçlara göre yüksek oranda çoklu antibiyotik dirençliliği (\%89.3), yüksek oranda (\%100) sefotaksim, siprofloksasin, gentamisin, seftazidime karşı duyarlılık ve incelenen suşların tamamında sınıf 1 integron varlığı tespit edildi. Sonuç olarak, Salmonella Infantis suşlarının hepsinde sınıf 1 integronların varlığı, bu suşların potansiyel direnç alıcı haline gelmesi bakımından önem taşıdığını göstermektedir.
\end{abstract}

Anahtar sözcükler: Antimikrobiyal direnç, Salmonella Infantis, Sınıf I integron

\section{İletişim (Correspondence) \\ +90312 3170315/4374 \\ inciibasak@hotmail.com}




\section{INTRODUCTION}

Non-typhiodal Salmonella infection is one of the most significant health problem in poultry all over the world particularly in developing countries ${ }^{[1]}$. Salmonella is also the most important zoonotic pathogen in poultry ${ }^{[2]}$ Salmonella may be transmitted to the raw chicken meat by improper evisceration of the intestine at the slaughterhouse which leads to food-borne infections in humans. On the other hand, Salmonella isolates carrying the antibiotic resistant genes are also important for both human and animal health ${ }^{[3]}$. According to the European Food Safety Authority (EFSA), among Salmonella serovars Salmonella Infantis is the most commonly reported serovar in poultry flocks ${ }^{[4]}$. In Turkey, the prevalence of $S$. Infantis serovar from healthy broiler chicken flocks is $77.2 \%$ by percentage ${ }^{[5]}$.

In Argentina, Australia, Brazil, Netherlands, Finland, Canada, Hungary, Japan, New Zealand and Russia this serovar has increasingly been reported and multidrug-resistant (MDR) Salmonella has been observed for more than 20 years ${ }^{[6,7]}$. Most of the antimicrobial resistance genes are integrated in mobile genetic elements such as plasmids, transposons and integrons ${ }^{[1,8,9]}$. Typically, Class 1 integrons have int/1 gene which encodes integrase, a recombination specific site, a promoter and gene cassettes. They can be inserted into transposons/plasmids and carry antibiotic resistance genes from bacteria to bacteria. Class 1 integrons harbor more than 100 gene casettes some of which are encoding resistance to $\beta$-lactamases, rifampicin, trimethoprim, aminoglycosides, quinolones and chloramphenicol ${ }^{[10,11]}$. Class 1 integrons are the most frequent integron type classified in MDR Salmonella serotypes ${ }^{[12,13]}$.

In recent years, several studies have been conducted to investigate integrons in Salmonella ${ }^{[8,9,12,13]}$. For example a study in Germany demonstrated that all S. Derby isolates obtained from pigs had Class 1 integrons. Another study in Thailand showed that 84 of 183 Salmonella strains (S. Anatum, S. Kedougou, S. Stanley, S. Weltevreden, S. Rissen, $S$. Baiboukoum) which were isolated from humans and pork had Class 1 integrons and 18 of the strains carried resistance gene cassettes ${ }^{[12,13]}$. Nevertheless, information of antimicrobial resistance related integrons of $S$. Infantis is limited in Turkey. Because of the relative prevalence of $S$. Infantis to other Salmonella serotypes in poultry production has increased in recent years, in this study multiple antibiotic resistance and the presence of Class 1 integrons related with antibiotic resistance was investigated in S. Infantis strains.

\section{MATERIAL and METHODS}

\section{Salmonella Strains and Antimicrobial Susceptibility Tests}

A total of $150 \mathrm{~S}$. Infantis strains selected among $206 \mathrm{~S}$. Infantis strains which were isolated from feces of healthy broiler chickens between 2012-2013 were used in this study. 150 strains were selected from four different regions (57 from Black Sea region, 39 from Central Anatolia, 30 from Aegean and 24 from Mediterranean region) of Turkey according to the capacity of flocks. Briefly, a $10 \%$ systematic sampling method was used for the flocks which were below 10.000 broiler chickens (Table 1). The isolation method and serotyping was performed according to the ISO 6579-2002 and Kauffmann-White scheme, respectively. Antimicrobial resistance of the strains was detected by the disc diffusion method following to the recommendations of CLSI 2011 standard protocol. Discs were used as follows: ampicillin (AMP: $10 \mu \mathrm{g}$ ); cefotaxime (CTX: 30 $\mu \mathrm{g})$; chloramphenicol (C: $30 \mu \mathrm{g})$; ciprofloxacin (CIP: $5 \mu \mathrm{g})$; gentamicin (GM: $10 \mu \mathrm{g})$; kanamycin (K: $30 \mu \mathrm{g})$; nalidixic acid (NA: $30 \mu \mathrm{g})$; streptomycin (S: $10 \mu \mathrm{g})$; tetracycline (TE: $30 \mu \mathrm{g})$; trimethoprim- sulfamethoxazole (SXT: $5 \mu \mathrm{g}$ ); sulfonamide (S3: $250 \mu \mathrm{g}$ ) and ceftazidime (CAZ: $30 \mu \mathrm{g}$ ). Escherichia coli ATCC 25922 and Pseudomonas aeruginosa ATCC 27853 were used as positive control in all tests.

\section{DNA Extraction}

DNA was extracted from the isolates with a commercial kit (Genomic DNA Purification, Thermo Fisher Scientific, USA) following the manufacturer's recommended protocol. Then, all samples were kept in $-20^{\circ} \mathrm{C}$ until the PCR assay was performed.

\section{PCR Amplification of the int/1 Gene}

Integrons were investigated by the detection of int/1 gene ${ }^{[14]}$. PCR amplification was performed containing 0.2 $\mu \mathrm{M}$ of each primer (int1-F 5'-GCC TTG CTG TTC TTC TAC-3', int1-R 5'-GAT GCC TGC TTG TTC TAC-3'), 0.2 mM dNTPs (10 mM dNTP mix; Thermo Fisher Scientific, USA), $3 \mathrm{mM}$ of $\mathrm{MgCl}_{2}$ (Thermo Fisher Scientific, USA), $2.5 \mu \mathrm{L}$ PCR reaction buffer, $2 \mathrm{U}$ of Taq DNA polymerase (Thermo Fisher Scientific; EP0402), and nuclease-free water to a final volume of 25 $\mu \mathrm{l}$. In the reaction, $2 \mu \mathrm{L}$ of DNA was used as template. The amplification was performed as follows: strand separation at $94^{\circ} \mathrm{C}$ for $3 \mathrm{~min}$, followed by 30 cycles of $94^{\circ} \mathrm{C}$ for $1 \mathrm{~min}$, $55^{\circ} \mathrm{C}$ for $1 \mathrm{~min}$, and $72^{\circ} \mathrm{C}$ for $1 \mathrm{~min}$. Finally, there was a $7 \mathrm{~min}$ at $72^{\circ} \mathrm{C}$ for further strand extension. Ten microliters of the amplified PCR products were analyzed by electrophoresis on $1.5 \%$ agarose gel (Promega Corporation, USA) with $4 \mu \mathrm{L}$ of SafeView Classic (Applied Biological Materials, Canada) in Gel Electrophoresis Apparatus with $180 \mathrm{~V}$ for 60 min. Positive (AVMA-SI14/2 Salmonella Infantis strain) and negative (Leptospira spp., Listeria spp., Bordatella spp., Ornithobacterium rhinotracheale, Streptococcus spp. and Pseudomonas spp.) strains were obtained from strain collection of Ankara University Faculty of Veterinary Medicine Department of Microbiology.

\section{RESULTS}

The isolates showing resistance to at least four and more antibiotic drug resistance were assessed as multiple- 


\begin{tabular}{|c|c|c|c|c|}
\hline Regions/City & $\begin{array}{l}\text { Number } \\
\text { of Total Flocks }\end{array}$ & $\begin{array}{c}\text { Number of Flocks } \\
\leq 10.000\end{array}$ & $\begin{array}{c}\text { Number of Flocks with } \\
10 \% \text { Sampling }\end{array}$ & $\begin{array}{l}\text { Number } \\
\text { of Isolates }\end{array}$ \\
\hline Black Sea/Bolu & 378 & 70 & 7 & 57 \\
\hline Central Anatolia/Çorum & 60 & 3 & $0.3^{*}$ & 7 \\
\hline Central Anatolia/Ankara & 20 & 9 & $0.9^{*}$ & 19 \\
\hline Central Anatolia/Afyonkarahisar & 70 & 2 & $0.2^{*}$ & 13 \\
\hline Aegean/Izmir & 55 & 4 & $0.4^{*}$ & 30 \\
\hline Mediterranean/İçel & 92 & 41 & 4 & 24 \\
\hline
\end{tabular}

\begin{tabular}{|c|c|c|}
\hline Antimicrobials & Number of Isolates & Resistance Rates (\%) \\
\hline AMP & 10 & 6.6 \\
\hline C & 11 & 7.3 \\
\hline K & 66 & 44 \\
\hline$S$ & 117 & 78 \\
\hline SXT & 122 & 81.3 \\
\hline S3 & 139 & 92.6 \\
\hline TE & 140 & 93.3 \\
\hline NA & 142 & 94.6 \\
\hline CTX & 0 & 0 \\
\hline CIP & 0 & 0 \\
\hline GM & 0 & 0 \\
\hline CAZ & 0 & 0 \\
\hline
\end{tabular}

Table 3. Antimicrobial resistance patterns of 134 MDR Salmonella Infantis isolates

\begin{tabular}{|l|c|}
\hline Multiple Resistance Patterns & Number of Isolates (\%) \\
\hline K, NA, S, TE, SXT, S3 & $46(30.6)$ \\
\hline K, NA, TE, SXT, S3 & $6(4)$ \\
\hline K, NA, S, TET, S3 & $5(3.3)$ \\
\hline NA, S, TE, S3 & $8(5.3)$ \\
\hline NA, TE, SXT, S3 & $13(8.6)$ \\
\hline NA, S, TE, SXT, S3 & $43(28.6)$ \\
\hline AMP, C, NA, S, TE, SXT, S3 & $2(1.3)$ \\
\hline AMP, K, NA, S, TE, SXT, S3 & $1(0.6)$ \\
\hline AMP, C, NA, S, TE, S3 & $1(0.6)$ \\
\hline AMP, NA, S, TE, SXT, S3 & $1(0.6)$ \\
\hline AMP, C, K, NA, S, TE, SXT, S3 & $4(2.6)$ \\
\hline C, K, NA, S, TE, SXT, S3 & $3(2)$ \\
\hline C, NA, S, TE, SXT, S3 & $1(0.6)$ \\
\hline
\end{tabular}

resistant strains. One hundred forty two $(94.6 \%)$ isolates were resistant to nalidixic acid, 140 (93.3\%) isolates were resistant to tetracycline, $139(92.6 \%)$ isolates were resistant to sulfonamide and $122(81.3 \%)$ isolates were resistant to trimethoprim- sulfamethoxazole (Table 2). Also, all isolates were sensitive to cefotaxime, ciprofloxacin, gentamicin and ceftazidime (100\%). Furthermore, 134 (89.3\%) multidrug resistance isolates were demonstrated (Table 3).

All samples were investigated for the presence of int/1 gene and thus the Class 1 integron (int/1 gene) was detected in all isolates. Beside this, all multi-drug resistant isolates have been found to have Class 1 integron.

\section{DISCUSSION}

Increasing antibiotic resistance is an important public health problem and resistance continues to spread due to many factors. Antibiotics used for therapeutic and prophylactic purposes for broilers as stimulating growth in production. Some antibacterial drugs, such as ampicillin, tetracycline, chloramphenicol, enrofloxacin, neomycin, which a re u sed in antibacterial treatment of Salmonella infections to become resistant by inhibiting the microflora of the digestive system and these bacteria play an important role in the transfer of resistance genes and cause serious infections that affect the food chain when spreading in nature ${ }^{[15-18]}$. For all these reasons, after January 2006, antibiotic feed additives are not allowed to be imported to Turkey by law ${ }^{[19]}$.

In the present study, antibiotic susceptibility and presence of Class 1 integron of $150 \mathrm{~S}$. Infantis strains that were isolated from healthy broiler chickens feces were detected. Nogrady et al. ${ }^{[20]}$ also conclude that $S$. Infantis strains, which had multiple resistance spread through the poultry meat among humans and this supported that MDR has become a public health concern. According to the European Food Safety Authority (EFSA) report, it was emphasized that $S$. Infantis strains detected in poultry resistant to tetracycline, ampicillin and sulphonamides and 31\% of MDR of these isolates ${ }^{[4]}$. Similar studies related to antibiotics that was used by poultry industry, performed by other researchers. Kudaka et al. ${ }^{[21]} 99.2 \%$ of broiler isolates were identified as $S$. Infantis and antimicrobial resistance strains were detected as tetracycline, streptomycin and trimetoprim and especially sulphanamide. In our study, the resistance of nalidixic acid, tetracycline and sulfonamide against S. Infantis is $94.6 \%, 93.3 \%, 92.6 \%$ respectively. The high resistance rate of $S$. Infantis to quinolones was known in 
Germany and Hungary, but in our study we had an opposite result of $100 \%$ sensitivity of ciprofloxacin ${ }^{[19]}$. Resistance to ciprofloxacin was reported to be $66.7 \%$ to $100 \%$, especially in Germany, Slovakia, Bulgaria and Austria ${ }^{[4]}$, while the study strains showed sensitivity to ciprofloxacin. Also high frequency of resistance to ciprofloxacin and nalidixic acid for S. Infantis was reported in several reports in Iran too ${ }^{[22,23]}$. Quinolones were used frequently in treatment regimens and also as a feed additives in poultry industry ${ }^{[24]}$. In recent years several studies have been reported about third-generation cephalosporin resistance patterns of Salmonella was isolated from domestic animals and human ${ }^{[25-27]}$. In parallel with this situation, Kameyama et al. emphasized that 3rd-generation cephalosporin-resistant $S$. Infantis associated with $\beta$-lactamases is increasing in worldwide ${ }^{[28]}$. Although cefotaxime and ceftazidime resistance were found in their research ${ }^{[28]}$, our isolates were $100 \%$ sensitive.

Furthermore, in this study, it was observed that multiple antibiotic resistance was directly proportional to Class 1 integron presence. In our study S. Infantis strains were investigated for the presence of int/1 gene and Class 1 integron was detected in all isolates. Previously, several laboratories mentioned that antibiotic resistance genes are chromosomally encoded and contain integrons. Integrons play an important role in the dissemination of antimicrobial resistance through horizontal transmission and it was known that prevalence of integron increases in Salmonella isolates ${ }^{[29,30]}$. Firoozeh et al. ${ }^{[8]}$ showed that poultry MDR Salmonella isolates were carried Class 1 integron 91.4\%, also Asgharpour et al. ${ }^{[1]}$ reported that S. Infantis strains contain $36 \%$ Class 1 integron in Iran. Naghoni et al. ${ }^{[31]}$ were detected Class 1 integron from $S$. enterica serovars and Kudaka et al. ${ }^{[21]}$ was revealed that presence of Class 1 integron in S. Infantis isolated from broiler chickens as our study. Several other researches have been reported in many different countries about Class 1 integron but $S$. Infantis studies were limited ${ }^{\text {[32-36] }}$. This situation is similar in Turkey. To our knowledge there is only one study conducted to determine the association of antibiotic resistance with integrons of $S$. Infantis strains ${ }^{[37]}$.

In our study, it was revealed that the antibiotic resistance rates were high in $S$. Infantis strains and a great number of these isolates have been found as MDR. Therefore, the more prudent usage of antibiotics and epidemiological studies are needed which can reveal the mechanism of spreading resistance and resistant strains must be included in prevention strategies.

\section{REFERENCES}

1. Asgharpour F, Rajabnia R, Shahandashti EF, Marashi MA, Khalilian M, Moulana Z: Investigation of Class I integron in Salmonella Infantis and its association with drug resistance. Jundishapur J Microbiol, 7, 1-5, 2013. DOI: 10.5812/jjm.10019

2. Lutful Kabir SM: Avian colibacillosis and salmonellosis: A clooser look at epidemiology, pathogenesis, diagnosis, control and public health concerns. Int J Environ Res Public Health, 7, 89-104, 2010. DOI: 10.3390/ ijerph7010089

3. Majitanova L, Majitan T, Majitan V: Detection of the Class 1 integrons and SGI1 among Salmonella enterica serovar Typhimurium DT104, U302, DT120, DT193 and nontypable human isolates. Jpn J Infect Dis, 63, 292295, 2010.

4. European Food Safety Authority: The European Union summary report on antimicrobial resistance in zoonotic and indicator bacteria from humans, animals and food in 2014. EFSA Journal, 14 (2): 4380, 2016.

5. Şahan Ö, Aral EM, Aden MMA, Aksoy A, Yılmaz Ö, Jahed R, Akan M: Türkiye'de broyler tavuk işletmelerinden izole edilen Salmonella serovarlarının antimikrobiyel direnç durumu. Ankara Üniv Vet Fak Derg, 63, 1-6, 2016.

6. Dionisi AM, Lucarelli C, Benedetti I, Owczarek S, Luzzi I: Molecular characterisatiobn of multidrug-resistant Salmonella enterica serotype Infantis from humans, animals and the environment in Italy. Int $J$ Antimicrob Agents, 38, 384-389, 2011. DOI: 10.1016/j.jjantimicag.2011.07.001

7. Miller T, Prager R, Rabsch W, Fehlhaber K, Voss M: Epidemiological relationship between Salmonella Infantis isolates of human and broiler origin. Lohman Information, 45 (2): 27-31, 2010.

8. Firoozeh F, Zahraei-Salehi T, Shahcheraghi F: Molecular clonality and detection of Class 1 Integron in multidrug-resistant Salmonella enterica Isolates from animal and human in Iran. Microb Drug Resist, 20, 517-524, 2014. DOI: 10.1089/mdr.2013.0198

9. Lopes GV, Michael GB, Cardoso M, Schwarz S: Antimicrobial resistance and Class 1 integron-associated gene casettes in Salmonella enterica serovar Typhimurium isolated from pigs at slaughter and abottoir environment. Vet Microbiol, 194, 84-92, 2016. DOI: 10.1016/j. vetmic.2016.04.020

10. Tseng CS, Yen YC, Chang CC, Hsu YM: Polymorphism of gene cassette promoter variants of Class 1 integron harbored in S. Choleraesuis and Typhimurium isolated from Taiwan. BioMedicine, 4 (3): 29-34, 2014. DOI: 10.7603/s40681-014-0020-3

11. Wu K, Wang F, Sun J, Wang Q, Chen Q, Yu S, Rui Y: Class 1 integron gene casettes in multidrug-resistant Gram-negative bacteria in southern China. Int J Antimicrob Agents, 40, 264-267, 2012. DOI: 10.1016/j. ijantimicag. 2012.05.017

12. Lopes GV, Michael GB, Cardoso M, Schwarz S: Identification and characterization of Salmonella enterica subsp. Enterica serovar Derby isolates carrying a new aadA26 gene cassette in a Class 1 integron obtained at pig slaughterhouses. Fems Microbiol Lett, 356, 71-78, 2014. DOI: $10.1111 / 1574-6968.12473$

13. Wannaprasat W, Padungtod $\mathbf{P}$, Chuanchuen R: Class 1 integrons and virulence genes in Salmonella enterica isolates from pork and humans. Int J Antimicrob Agents, 37, 457-461, 2010. DOI: 10.1016/j. ijantimicag.2010.12.001

14. Guerra B, Junker E, Miko A, Helmuth R, Mendoza MC: Characterization and localization of drug resistance determinants in multidrug-resistant, integron-carrying Salmonella enterica serotype Typhimurium strains. Microb Drug Resist, 10, 83-91, 2004. DOI: 10.1089/1076629041310136

15. Bilgili A: Kanatlılarda antibakteriyel ilaç kullanım seçenekleri ve sakıncaları. Ankara Üniv Vet Fak Derg, 41, 243-253, 1994.

16. Carraminana JJ, Rota C, Agustin I, Herrera A: High prevalence of multiple resistance to antibiotics in Salmonella serovars isolated from a poultry slaughterhouse in Spain. Vet Microbiol, 104, 133-139, 2004. DOI: 10.1016/j.vetmic.2004.08.010

17. Molbak K: Human health consequences of antimicrobial drugresistant Salmonella and other foodborne pathogens. Food Saf, 41, 16131620, 2005. DOI: 10.1086/497599

18. Tessari ENC, Kanashiro AMI, Stoppe GFS, Luciano LR, Castro AGM, Cardoso ALSP: Important aspects of Salmonella in the poultry industry and in Public. In, Mahmoud BSM (Ed): Salmonella-A Dangerous Foodborne Pathogen. 181-206, InTech, Rijeka, Croatia, 2012.

19. Anonim: Yem Katkıları ve Premikslerin Üretimi, İthalatı, İhracatı, Satışı ve Kullanımı Hakkında Tebliğde Değişiklik Yapılmasına Dair Tebliğ. Tarım 
ve Köyişleri Bakanlığından. 21 Ocak 2006. Sayı: 26056 Tebliğ No: 2006/1 Resmi Gazete, 2006.

20. Nogrady N, Toth A, Kostyak A, Paszti J, Nagy B: Emergence of multidrug resistance clones of Salmonella Infantis in broiler chickens and humans in Hungary. J Antimicrob Chemother, 60,645-648, 2007. DOI: 10.1093/jac/dkm249

21. Kudaka J, Itokazu K, Taira K, Iwai A, Kondo M, Susa T, Iwanaga M: Characterization of Salmonella isolated in Okinawa, Japan. Jpn J Infect Dis, 59, 15-19, 2006.

22. Morshed R, Peighambari SM: Drug resistance, plasmid profile and random amplified polymorphic DNA analysis of Iranian isolates of Salmonella Enteritidis. New Microbiol, 33, 47-56, 2010.

23. Rahmani M, Peighambari SM, Svendsen CA, Cavaco LM, Agerso Y, Hendriksen RS: Molecular clonality and antimicrobial resistance in Salmonella enterica serovars Enteritidis and Infantis from broilers in three Northern regions of Iran. BMC Vet Res, 9, 66, 2013. DOl: 10.1186/17466148-9-66

24. Kim KY, Park JH, Kwak HS, Woo GJ: Characterization of the quinolone resistance mechanism in foodborne Salmonella isolates with high nalidixic acid resistance. Int J Food Microbiol, 146, 52-456, 2011. DOI: 10.1016/j.jifoodmicro.2011.01.037

25. Burke L, Hopkins KL, Meunier D, de Pinna E, Fitzgerald-Hughes $D_{\text {, }}$ Humphreys $\mathbf{H}$, Woodford $\mathrm{N}$ : Resistance to third-generation cephalosporins in human non-typhoidal Salmonella enterica isolates from England and Wales, 2010-12. J Antimicrob Chemother, 69, 977-981, 2014. DOI: 10.1093/ $\mathrm{jac} / \mathrm{dkt} 469$

26. Izumiya H, Mori $K$, Higashide M, Tamura K, Takai N, Hirose $K$ Terajima J, Watanabe H: Identication of CTX-M-14 $\beta$-lactamase in a Salmonella enterica serovar Enteritidis isolate from Japan. Antimicrob Agents Chemother, 49, 2568-2570, 2005. DOI: 10.1128/AAC.49.6.25682570.2005

27. Liakopoulos A, Geurts Y, Dierikx CM, Brouwer MSM, Kant A, Wit B, Heymans R, van Pelt W, Mevius DJ: Extended-spectrum cephalosporin resistant Salmonella enterica serovar Heidelberg strains, the Netherlands. Emerg Infect Dis, 22, 1257-1261, 2016. DOI: 10.3201/eid2207.151377

28. Kameyama M, Chuma T, Yokoi T, Yabata J, Tominaga K, Miyasako

D, Iwata H, Okamoto K: Emergence of Salmonella enterica serovar
Infantis harboring Incl1 Plasmid with blaCTX-M-14 in a broiler farm in Japan. J Vet Med Sci, 74, 1213-1216, 2012. DOI: 10.1292/jvms.11-0488

29. Poirel L, Carrer A, Pitout JD, Nordmann P: Integron mobilization unit as a source of mobility of antibiotic resistance genes. Antimicrob Agents Chemother, 53, 2492-2498, 2009. DOI: 10.1128/AAC.00033-09

30. Roy CP, Ingold A, Vanegas N, Martinez E, Merlino J, Merkier AK: Dissemination of multiple drug resistance genes by Class 1 integrons in Klebsiella pneumoniae isolates from four countries: A comparative study. Antimicrob Agents Chemother, 55, 3140-3149, 2011. DOI: 10.1128/ AAC.01529-10

31. Naghoni A, Ranjbar R, Tabaraie B, Farshad S, Owlia P, Safiri Z: High prevalence of integron-mediated resistance in clinical isolates of Salmonella enterica. Jpn J Infect Dis, 63, 417-21, 2010.

32. Khan AA, Ponce E, Nawaz MS, Cheng CM, Khan JA, West CS: Identification and characterization of Class 1 integron resistance gene cassettes among Salmonella strains isolated from imported sea-food. Appl Environ Microbiol, 75, 1192-1196, 2009. DOI: 10.1128/AEM.02054-08

33. Molla B, Miko A, Pries K, Hildebrandt G, Kleer J, Schroeter A: Class 1 integrons and resistance gene cassettes among multidrug resistant Salmonella serovars isolated from slaughter animals and foods of animal origin in Ethiopia. Acta Trop, 103, 142-149, 2007. DOI: 10.1016/j. actatropica.2007.05.018

34. Zhao S, Fedorka-Cray PJ, Friedman S, McDermott PF, Walker RD, Qaiyumi S: Characterization of Salmonella Typhimurium of animal origin obtained from the National Antimicrobial Resistance Monitoring System. Foodborne Pathog Dis, 2, 169-681, 2005. DOI: 10.1089/fpd.2005.2.169

35. Miko A, Pries K, Schroeter A, Helmuth R: Molecular mechanisms of resistance in multidrug-resistant serovars of Salmonella enterica isolated from foods in Germany. J Antimicrob Chemother. 56, 1025-1033, 2005. DOI: 10.1093/jac/dki365

36. Vo AT, van Duijkeren E, Gaastra W, Fluit AC: Antimicrobial resistance, class 1 integrons, and genomic island 1 in Salmonella isolates from Vietnam. PLoS One, 5, e9440, 2010. DOI: 10.1371/journal.pone.0009440

37. Abbasoğlu D, Akçelik M: Phenotypic and genetic characterization of multidrug-resistant Salmonella Infantis strains isolated from broiler chicken meats in Turkey. Biol J, 66, 406-410, 2011. DOI: 10.2478/s11756011-0051-0 